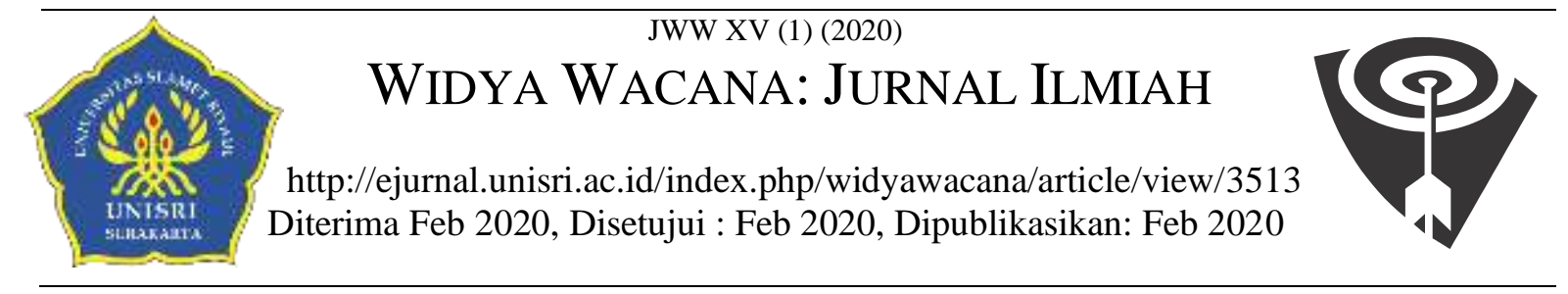

\title{
PENINGKATAN KEMAMPUAN GURU DALAM MELAKSANAKAN PEMBELAJARAN SAINTIFIK MELALUI SUPERVISI KLINIS TEKNIK CLASSROOM VISITATION BAGI GURU SMP NEGERI 2 AMPEL SEMESTER II TAHUN PELAJARAN 2018/2019
}

\author{
Sri Rahayu \\ Kepala Sekolah SMP Negeri 2 Ampel Kabupaten Boyolali \\ Email: srirahayu.2ampel@gmail.com
}

\begin{abstract}
ABSTRAK
Penelitian ini untuk menganalisis dan mendeskripsikan peningkatan kemampuan guru dalam pembelajaran saitifik bagi guru di SMPN 2 Ampel Semester II TP 2018/2019 melalui supervisi klinis teknik Classroom Visitation. Subjek penelitian ini adalah sebagian guru SMP Negeri 2 Ampel Kabupaten Boyolali sebanyak 6 (enam) guru. Penelitian ini dilaksanakan di SMPN 2 Ampel Kabupaten Boyolali dapa semester II. Penelitian dilaksanakan 2 (dua) siklus. Indikator kinerja ditetapkan: apabila semua guru telah mencapai nilai rata-rata minimal lebih dari 21,5 $(\geq 21,5)$. Hasil penelitian menunjukkan bahwa melalui tindakan pembinaan teknik classroom visitation, kemampuan guru di SMPN 2 Ampel Kabupaten Boyolali dalam pembelajaran saintifik meningkat dengan maksimal. Peningkatan dapat dilihat dari nilai rata-rata dari prasiklus ke ke siklus II dari 13,17 menjadi 29,17 (meningkat sebesar 16). Peningkatan prosentase ketercapaian indikator dari kegiatan prasiklus sebesar ke siklus II dari $41,15 \%$ menjadi $91,15 \%$ (meningkat sebesar 50,00\%).
\end{abstract}

Kata Kunci: pembelajaran saintifik, classroom visitation

\begin{abstract}
This study is to analyze and describe the improvement of the ability of teachers in positive learning for teachers at SMPN 2 Ampel Semester II TP 2018/2019 through clinical supervision of Classroom Visitation techniques. The subjects of this study were 6 (six) teachers from SMP Negeri 2 Ampel in Boyolali Regency. This research was conducted at SMPN 2 Ampel Boyolali Regency in the second semester. The study was conducted in 2 (two) cycles. Performance indicators are established: if all teachers have achieved a minimum grade point average of more than $21.5(\geq 21.5)$. The results show that through classroom visitation techniques, the ability of teachers at SMPN 2 Ampel Boyolali Regency in scientific learning increases to the maximum. The increase can be seen from the average value from pre-cycle to cycle II from 13.17 to 29.17 (an increase of 16). The increase in the percentage of achievement indicators from pre-cycle activities amounted to cycle II from $41.15 \%$ to $91.15 \%$ (an increase of $50.00 \%$ ).
\end{abstract}

Keywords: scientific learning, classroom visitation

\section{PENDAHULUAN}

Pelaksanaannya K13 di SMP Negeri 2 Ampel masih terdapat beberapa permasalahan, khusus terkait dengan aktivitas guru dalam mengimplementasikan pembelajaran saintifik. Kurikulum 2013 lebih menekankan pada pembelajaran dengan pendekatan berpusat pada siswa (Student Centered Learning). Implementasi pembelajaran kurikulum 2013, mewajibkan siswa selalu aktif dalam proses pembelajaran.

Sebelum diterapkan kurikulum 2013, guru menggunakan model pembelajaran yang kurang mendorong siswa untuk terlibat langsung dalam proses pembelajaran, sehingga untuk mengubah pola pembelajaran tersebut, membutuhkan waktu dan perlu pembinaan secara terus menerus. Keaktifan siswa dalam pelaksanaan kurikulum 2013 
merupakan hal yang penting dalam pembelajaran. Khususnya di SMP Negeri 2 Ampel, namun guru menomor duakan hal tersebut. Beberapa guru masih berasumsi bahwa proses pembelajaran merupakan kegiatan yang sekedar sarana penyampaian informasi tanpa mendukung berkembangnya aktivitas siswa.

Hasil pantauan terhadap proses pembelajaran di SMP Negeri 2 Ampel selama 1 (satu) semester yaitu pada semester I Tahun Pelajaran 2018/2019, ternyata pelaksanan kurikulum 2013 di SMP Negeri 2 Ampel masih terdapat permasalahan yang serius, yaitu masih adanya guru belum dapat melaksanakan pembelaajran saintifik dengan baik. Hal ini terindikasi dari aktivitas guru dalam melaksanakan kegiatan pembelajaran masih banyak kekurangan. Guru banyak mendominasi aktivitas dalam pembelajaran. Pada kegiatan penutup guru tidak merefleksikan kegiatan pembelajaran, dan tidak menyampaikan penilaian kepada siswa.

Kenyataan tersebut dapat dimaknai bahwa, kinerja guru di SMP Negeri 2 Ampel, khususnya terkait dengan aktivitas guru selamam proses pembelajaran berlangsung, yaitu melalui pembinaan khusus dengan teknik Supervisi klinis teknik Classroom visitation, sehingga diharapkan melalui supervisi khusus tersebut secara bertahap semua guru yang ada di SMPN 2 Ampel memiliki kemampuan yang baik dalam melaksanakan pembelajaran kurikulum 2013.

Mengingat permasalahan guru dalam melaksanakan kuikulum 2013 antara guru satu dengan lainya berbeda, maka untuk melaksanakan supervisi perlu dipilih teknik yang tepat, yaitu dengan menerapkan pembinaan individu teknik classroom visitation, yaitu teknik supervisi yang dilakukan dengan cara mengunjungi kelas, ketika guru sedang melaksanakan pembelajaran. Adapun teknik pembianan berikutnya dapat dilakukan melalui percakapan pribadi. Teknik ini dipilih karena guru di SMP Negeri 2 Sebenarnya telah memiliki pengalaman dan telah mengikuti berbagai pembinaan terkait dengan pelaksanaan kurikulum 2013, sehingga melalui classroom visitation dan pembinaan berikutnya, kekurangan guru dapat diperbaiki.

Sesuai dengan karakteristik permasalahan dan tindakan perbaikan yang dilakukan, maka agar tindakan perbaikan ini dapat berjalan dengan efektif, maka tindakan ini dirancang dalam bentuk penelitian tindakan sekolah (PTS) yaitu suatu tindakan nyata untuk mengatasi permasalahan rendahnya kinerja guru dalam melaksanakan pembelajaran kurikulum 2013, dengan judul penelitian: "Peningkatan Kemampuan Guru dalam Melaksanakan Pembelajaran Saintifik Melalui Supervisi Klinis Teknik Classroom Visitation bagi Guru SMP Negeri 2 Ampel Tahun Pelajaran Semester II Tahun Pelajaran 2018/2019.

\section{Perumusan Masalah}

"Apakah supervisi klinis teknik Classroom Visitation dapat meningkatkan kemampuan guru melaksanakan pembelajaran saintifik bagi guru di SMPN 2 Ampel Semester II Tahun Pelajaran 2018/2019?

\section{Tujuan Penelitian}

Penelitian ini bertujuan untuk menganalisis dan mendeskripsikan peningkatan kemampuan guru dalam melaksanakan pembelajaran saitifik bagi guru di SMPN 2 Ampel Semester II Tahun 2018/2019 melalui supervisi klinis teknik Classroom Visitation.

\section{KAJIAN TEORI DAN HIPOTESIS TINDAKAN \\ Kemampuan Guru}

Berbagai pendapat tentang kemampuan guru, dikemukakan oleh para ahli diantaranya: Wijaya (2010: 7) menjelaskan bahwa kemampuan guru menggambarkan kualitas perilaku yang dimiliki oleh seorang guru. Kunandar (2008: 52) lebih menekankan pada potensi yang dimiliki oleh seorang guru terhadap beban tugas. Sedangkan Sarimaya (2008: 17) arti kemampuan guru tersabut lebih ditekankan pada pengetahuan, keterampilan, dan perilaku guru yang diimplementasikan dalam bentuk unjuk kerja. 
Dari pendapat tersebut dapat diartikan bahwa Kompetensi guru adalah gambaran kualitas perilaku yang merupakan potensi dalam mengemban tugas kompetensi guru sendiri diwujudkan dalam dimilikinya aspek pengetahuan, ketrampilan dan perilaku.

\section{Pelaksanaan Pembelajaran}

Pengajaran atau pelaksanaan pembelajaran diartikan sebagau suatu proses interaksi antara guru dengan peserta didik dan sebaliknya, atau interaksi antara peserta didik dengan peserta didik lainya. Guru mempunyai tanggung jawab dalam pelaksanaan pembelajaran yaitu mengeola pengajaran agar dapat terlaksanakan dengan efektif. Mengajar pada prinsipnya adalah aktivitas guru untuk menstranfer pengetahuan, prinsip tersebut merupakan pandangan tradisional, padahal pengajaran merupakan aktivitas yang sangat kompleks (Hasibuan, 2010: 37). Artinya pengajaran tidak hanya sekedar menyampaikan pengetahuan, tetapi pengajaran merupakan aktivitas guru dalam mempersiapkan pengalamana belajar bagi peserta didik.

\section{Pembelajaran Kurikulum 2013}

Pelaksanaan pembelajaran harus selalu berbedoman pada kurikulum, sehingga dari kurikulum tersebut guru mengembangkan dalam bentuk silabus dan rencana pelaksanaan pembelajaran. Pembelajaran dalam kurikulum 2013 merupakan pedoman bagi guru dalam mencapai tujuan pengajaran (Dakir, 2010: 3). Agar pelaksanaan pembelajaran sesuai dengan apa yang dimaksudkan dalam kurikulum 2013, maka dalam mengembangkan kurukulum ke dalam rencana yang lebih operasional (Rencana pelaksanaan pembelajaran), maka guru harus memahami isi dari kurikulum 2013 tersebut dengan baik. Kurikulum 2013 merupakan pengembangan dari KTSP atau kurikulum 2016 diterapkan mulai tahun ajaran 2013/2014 secara bertahap (Fadlillah, 2014: 16).

\section{Pembinaan}

Pembinaan merupakan bentuk tindakan dan proses untuk meningkatkan kualitas sumber daya manusia agar lebih baik (Thoha, 2011: 78), melalui pembinaan diharapkan adanya peningkatan kinerja, kemajuan, pngembangan, atau pertumbuhan sesuai dengan tunuan pembinaan. Tujuan pembinaan guru merupakan suatu tindakan untuk memperbaiki kinerja guru dalam melaksanakan tugas pokok guru yaitu melaksanakan pengajaran. Pembinaan guru merupakan upaya untuk mengembangkan profesionalisme guru agar dapat memberikan kontribusi dalam dunia pendidikan (Rohim, 2011).

\section{Classroom Visitation}

Purwanto (2010: 120) mengartikan kunjungan kelas sebagai kegiatan kepala sekolah maupun pengawas untuk mengunjungi kelas bahwa kunjungan kelas saat guru melaksanakan proses pembelajaran. Kunjungan tersebut bertujuan untuk memperoleh gambaran nyata dari aktivitas guru dalam melaksanakan pengajaran. Namun ada kalanya kunjungan tersebut dilakukan pada saat guru menghadapi permasalahan terkait dengan tugas pokoknya (Priansa dan Somad, 2014: 99). Berbeda dengan kunjungan antar kelas, kunjungan antara kelas merupakan kunjungan guru yang dilakukan ke kelas lain dalam satu sekolah (Sagala, 2009: 217) adapun tujuan dari kunjungan antar kelas ini adalah agar guru saling memperoleh pengalaman dari guru lain terkait dengan pelaksanaan tugas guru sebagai pendidik. Melalui kunjungan antar kelas ini diharapkan guru memperoleh pengalaman yang berharga dari guru yang dikunjungi. Suhertian (2010: 79) berpendapat bahwa kunjungan antar kelas merupakan kegiatan saling guru untuk saling mengunjungi saat mengajar.

\section{Kerangka Pemikiran}

Hasil pantauan awal tentang kemampuan guru SMPN 2 Ampel selama 1 (satu) semester yaitu pada semester I Tahun Pelajaran 2018/2019, ternyata pelaksanan kurikulum 2013 masih terdapat permasalahan yang serius, yaitu masih adanya guru yang belum memiliki kemampuan yang baik dalam melaksanakan pembelajaran kurikulum 2013, sehingga perlu diperbaiki melalui supervisi secara khusus secara bertahap. 
Mengingat permasalahan guru dalam melaksanakan kuikulum 2013 antara guru satu dengan lainya berbeda, maka untuk melaksanakan supervisi perlu dipilih teknik yang tepat, yaitu dengan menerapkan teknik Classroom Visitation, dengan harapan setelah dilakukan pembinaan.

\section{Hipotesis Tindakan}

Supervisi klinis teknik Classroom Visitation kemampuan guru SMPN 2 Ampel Kabupaten Boyolali Semester II Tahun Pelajaran 2018/2019 dalam melaksanakan pembelajaran saintifik dapat meningkat.

\section{METODE PENELITIAN TINDAKAN Desain Penelitian Tindakan}

PTS merupakan tindakan memecahkan permasalahan nyata yang terjadi di sekolah melalui tindakan perbaikan (Arikunto. 2010: 42). Penelitian ini dilakukan karena ditemukan permasalahan yaitu rendahnya kemampuan guru dalam melaksanakan pembelajaran saintifik di SMP Negeri 2 Ampel Kabupaten Boyolali. Sebagai tindakan nyata untuk memperbaiki permasalaahan tersebut adalah melalui pembinaan teknik classroom visitation.

\section{Subjek Penelitian}

Penelitian ini mengambil subjek sebagian guru SMPN 2 Ampel Kabupaten Boyolali sebanyak 6 (enam) guru, yang titunjuk oleh kepala sekolah. Hal ini disebabkan adanya permasalahan dimana guru kurang memahami langkah-langkah dalam melaksanakan pembelajaran saintifik, sehingga perlu adanya tindakan nyata untuk mengatasi permasalahan tersebut.

\section{Objek Penelitian}

Pengertian objek penelitian menurut Arikunto (2010: 56) adalah variabel yang menjadi titik perhatian suatu penelitian. Objek penelitian adalah peningkatan kemampuan guru dalam melaksanakan pembelajaran saintifik.

\section{Lokasi dan Waktu Penelitian}

PTS ini dilaksanakan di SMP Negeri 2 Ampel Kabupaten Boyolali beralamat di jln. Candi No.2, Kudorejan, Urutsewu, Kecamatan Ampel, Kabupaten Boyolali. Dipilihnya lokasi tersebut, karena peneliti adalah kepala sekolah SMP tersebut, yang secara nyata masih terdapat permasalahan terkait dengan kemampuan guru dalam melaksanakan pembelajaran saintifik pada semester II tahun pelajaran 2018/2019, dimulai bulan Januari sampai dengan bulan Juni 2019.

\section{Teknik Pengumpulan Data}

Data penelitian ini diperoleh melalui melalui observasi langsung, untuk menilai kinerja guru dalam melaksanakan pembelajaran saintifik, penilaian menggunakan 0,1 , dan 2 pada setiap indikator.

\section{Teknik Analisa Data}

Untuk menganalisis data, peneliti menggunakan teknik analisis deskriptif, dengan cara membandingkan hasil penilaian antar sikluls. Dari perbandingan hasil penilaian antar siklus akan diperoleh gambaran perkembangan kinerja guru dalam melaksanakan pembelajaran saintifik. Penyajian hasil analisis dibuat dalam bentuk tabel dan grafik agar mudah dipahami. Berdasarkan hasil penilaian, untuk menganalisis penguasaan guru dalam melaksanakan pembelajaran, digunakan pendekatan presentase (Rusliana, 2007:6).

\section{Indikator Kinerja}

Untuk mengukur tingkat keberhasilan tindakan. Hasil penelitian dikatakan berhasil apabila semua guru telah mencapai nilai kompetensi dengan kategori baik, dengan nilai rata-rata minimal lebih dari 21,5 ( $\geq$ 21,5), dengan prosentase penguasaan indikator telah mencapai lebih dari $\geq 85 \%$.

\section{HASIL DAN PEMBAHASAN}

Prasiklus

Ringkasan hasil pengamatan prasiklus menunjukkan bahwa kemampuan guru dalam pembelajaran saintifik sebelum dilakukan tindakan adalah: nilai rata-rata sebesar 13,17 (cukup), nilai tertinggi 16,00 (cukup), nilai terendah 10,00 (kurang). Jumlah guru yang memperoleh nilai kategori baik belum ada, kategori cukup sebanyak 4 guru $(66,7 \%)$, dan nilai rendah sebanyak 2 guru $(33,3 \%)$. 
Hasil perhitungan prosentase ketercapaian indikator prasiklus dapat diketahui bahwa rata-rata prosentase ketercapaian yang diperoleh guru adalah $41,15 \%$. Hal ini menunjukkan bahwa guru di SMP Negeri 2 Ampel dalam melaksanakan pembelajaran saintifik belum maksimal sehingga perlu diupayakan langkah perbaikan melalui supervisi klinis.

Hasil penilaian siklus I menunjukkan bahwa skor rata-rata sebesar 23,83 (baik), dengan prosentasi penguasaan indikator ratarata sebesar $74,48 \%$. Hal ini menunjukkan bahwa setelah dilakukan pembinaan teknik Classroom Visitation, kemampuan guru dalam melaksanakan pembelajaran saintifik telah meningkat. Peningkatan tersebut disebabkan oleh tambahnya pengetahuan guru dan pemahaman guru terhadap langkah pelaksanaan pembelajaran saintifik sebagai dampak dari kunjungan kelas yang dilanjutkan dengan percakapan pribadi di ruang kelas. Namun jika dibanding dengan indikator keberhasilan yang telah ditetapkan, skor rata-rata dan prosentase ketercapaian tersebut belum dapat berhasil, sehingga harus dilakukan tindakan lanjutan dengan memperbaiki kekurangan guru melalui pembinaan teknik Classroom Visitation.

Hasil penilian siklus II diketahui bahwa skor rata-rata sebesar 29,17 (baik), dengan prosentasi penguasaan indikator ratarata sebesar $91,15 \%$. Hal ini menunjukkan bahwa setelah dilakukan pembinaan teknik classroom visitation, kemampuan guru dalam melaksanakan pembelajaran saintifik telah meningkat. Peningkatan tersebut disebabkan oleh tambahnya pengetahuan guru dan pemahaman guru terhadap langkah pelaksanaan pembelajaran saintifik yang benar yang diperoleh saat supervisi dilaksanakan. Dibanding dengan hasil penilaian siklus sebelumnya telah terjadi peningkatan. sehingga tindakan tidak perlu dilanjutkan.

\section{PEMBAHASAN}

\section{Perbandingan Nilai Rata-Rata}

Perbandingan nilai prasiklus dengan siklus I, menunjukkan bahwa nilai rata-rata dari prasiklus ke siklus I mengalami peningkatan 10,67. nilai tertinggi meningkat dari 16 menjadi 26, nilai terendah meningkat dari 10 menjadi 21, jumlah guru yang mendapat nilai baik dari tidak ada menjadi 5 guru, jumlah guru yang mendapat nilai cukup dari 4 guru turun menjadi 1 guru, jumlah guru yang memperoleh nilai rendah berkurang dari 2 guru menjadi tidak sama sekali.

Perbandingan nilai siklus I dengan siklus II, menunjukkan bahwa nilai rata-rata dari siklus I ke siklus II mengalami peningkatan sebesar 5,33, yaitu dari siklus I sebesar 23,83 siklus II menjadi 29,17. nilai tertinggi dari 26 menjadi 32, nilai terendah dari 21 menjadi 27, jumlah guru yang memperoleh nilai baik dari 5 Guru meningkat menjadi 6 guru, jumlah guru yang mendapat nilai cukup berkurang dari 1 guru menjadi tidak ada.

Perbandingan nilai prasiklus dengan siklus II, menunjukkan bahwa nilai rata-rata dari prasiklus ke siklus II mengalami peningkatan sebesar 16, yaitu dari prasiklus sebesar 13,17 siklus II menjadi 29,17. nilai tertinggi dari 16 menjadi 32, nilai terendah dari 10 menjadi 27, jumlah guru yang memperoleh nilai baik dari 0 menjadi 6Guru, jumlah guru yang mendapat nilai cukup berkurang dari 4 guru menjadi tidak ada. Guru yang memperoleh nilai rendah berkurang dari 2 menjadi tidak ada.

\section{Perbandingan Prosentase Penguasaan Indikator}

Perbandingan prosentase penguasaan indikator prasiklus dengan siklus I, dari $41,15 \%$ meningkat menjadi $74,48 \%$ artinya terjadi peningkatan sebesar $33,33 \%$. Siklus I ke siklus IIdari $74,48 \%$ menjadi $91,15 \%$ artinya terjadi peningkatan sebesar $16,67 \%$. Perbandingan prosentase penguasaan indikator prasiklus dengan siklus II, dari $41,15 \%$ menjadi $91,15 \%$ (peningkatan sebesar 50,00\%).

Berdasarkan perbandingan nilai ratarata dan prosentase ketercapaian indikator seperti diuraikan di atas dapat dikemukakan bahwa melalui pembinaan teknik classroom visitation dapat meningkatkan kemampuan guru. Peningkatan terjadi pada seluruh aspek penilaian. Hal ini menunjukkan bahwa dengan tindakan berupa pembinaan teknik classroom visitation mampu meningkatkan pemahaman guru terhadap komponen/aspek- 
aspek penilaian kemampuan guru dalam melaksanakan pembelajaran saintifik.

PENUTUP

Simpulan dari penelitian ini adalah "melalui tindakan supervisi klinis teknik Classroom Visitation, kemampuan guru dalam melaksanakan pembelajaran saintifik bagi guru SMPN 2 Ampel Kabupaten Boyolali meningkat dengan maksimal, dari 13,17 menjadi 29,17 (peningkatan sebesar 5,33). Peningkatan kinerja guru dalam melaksanakan langkah pembelajaran meningkat dari $41,15 \%$ menjadi $91,15 \%$. Hal ini membuktikan bahwa melalui supervisi klinis teknik classroom visitation dapat meningkatkan kemampuan guru dalam melaksanakan pembelajaran saintifik.

\section{DAFTAR PUSTAKA}

Arikunto, S. 2010. Prosedur penelitian: Suatu Pendekatan Praktik. Edisi Revisi. Jakarta: Rineka Cipta

Dakir, H.2010. Perencanaan dan pengembangan kurikulum. Jakarta : Rineka Cipta.

Fadlillah, M. $2014 . \quad$ Implementasi Kurikulum 2013 Dalam

Pembelajaran SD/MI,. SMP/MTs, \& SMA/MA. Yogyakarta: PT Ar-ruzz Media

Hasibuan dan Moedjiono. 2010. Proses BelajarMengajar. Bandung: PT. RemajaRosdakarya.

Kunandar. 2008. Penelitian Tindakan Kelas Sebagai Pengembangan Profesi Guru. Raja Grafindo Persada. Jakarta
Priansa, Donni Juni dan Rismi Somad. 2014. Manajemen Supervisi dan Kepemimpinan Kepala Sekolah. Bandung : CV Alfabeta

Purwanto, Ngalim, 2010, Atministrasi dan Supervisi Pendidikan, Bandung: PT Remaja Rosdakarya

Rohim, Abdul. 2011. Pembinaan Kompetensi Profesional Guru di SMP Cipondoh Tanggerang. Website: Pembinaan Kompetensi Mengajar.pdf

Rusliana, Ade, 2007, Konsep Dasar Evaluasi Belajar, http://www.oenoen.co.cc /2010/12/ konsep-dasarevaluasi.html, Diakses 07 Desember 2009.

Sagala Syaiful, 2009, Supervisi pembelajaran dalam profesi pendidikan, Bandung: Alfabeta.

Sahertian, Piet A., 2010, Konsep Dasar dan Tehnik Supervisi Pendidikan Dalam Rangka Mengembangkan Sumber Daya Manusia, Jakarta : Rineka Cipta

Sarimaya, Farida. 2008. Sertifikasi Guru, Apa, Mengapa dan Bagaimana. Bandung: CV. Yrama Widya.

Thoha, Miftah. 2011. Perilaku Organisasi, Konsep Dasar dan Aplikasinya. Rajawali Pers. Jakarta.

Wijaya A Cece. 2010. Kemampuan Dasar Guru Dalam Proses Belajar. Mengajar. Bandung : PT Remaja Rosda karya 